\title{
Ser e sentido: o paradoxo do sofrimento
}

\author{
Being and sense: the paradox of suffering \\ Oswaldo Giacoia Jr. \\ Professor Titular do Departamento de Filosofia da UNICAMP \\ E-mail:ogiacoia@hotmail.com
}

Resumo: Tomando como ensejo e base filosófica a obra de Arthur Schopenhauer, o artigo elabora uma reflexão sobre a natureza paradoxal do sofrimento na existência humana. A despeito de sua incontornável positividade - só o sofrimento é efetivamente real, bem estar é sempre a impermanente cessação do sofrimento -, ele é absurdo, e se implanta na raiz ontológica da finitude humana.

Palavras-chave: Finitude; Sofrimento; Vontade; Compaixão; Egoísmo.
Abstract: Taking as an opportunity and philosophical basis of the work of Arthur Schopenhauer, the article presents a reflection on the paradoxical nature of suffering in human existence. Despite its undeniable positivity - only suffering is actually real, wellbeing is always impermanent cessation of suffering - it is absurd, and is implanted in the ontological root of human finitude.

Keywords: Finitude; Suffering; Will; Compassion; Selfishness. 
$\mathrm{N}$ a filosofia moderna, Spinoza pode ser considerado o precursor de uma ética entendida como modo de ser ou forma de vida, baseada numa concepção original de liberdade como livre necessidade, uma ética não normativa, para a qual não faz sentido a prescrição de imperativos de dever ou normas de conduta com pretensões de validade universal. Regras morais, em Spinoza, consistem, antes, em expressões de sabedoria de vida, em preceitos racionais adequados para a gestão ativa dos afetos e controle sobre as paixões tristes, que diminuem a potência de existir de todo conatus.

Arthur Schopenhauer e Friedrich Nietzsche são, em boa medida, companheiros de viagem de Baruch de Spinoza, por mais que as respectivas filosofias evidenciem diferenças irreconciliáveis; pois esse entendimento de ética como forma de vida é comum a todos eles, assim como uma reflexão sobre liberdade e necessidade que impugna a doutrina tradicional do livre arbítrio. Nesse sentido, tanto a ética do caráter de Schopenhauer, como a justificação estética da existência de Nietzsche, paradoxalmente, a despeito de fundadas num respectivo conceito de vontade (de vida, num caso, de poder, no outro) seguem a trilha aberta por Spinoza de desconstrução dos sistemas morais baseados nos conceitos de vontade livre e na supressão da contradição entre liberdade e necessidade, operada por dispositivos teóricos diferentes daqueles mobilizados pelo conceito kantiano de razão prática.

No âmbito da filosofia contemporânea, embora também vinculados, por laços de natureza diferente, ao sistema crítico de Kant; Schopenhauer e Nietzsche são, cada um a seu modo, representantes de uma ética não deontológica, pois em nenhum dos casos figuram positivamente conceitos de lei moral universal, de deveres ou obrigações de conteúdo objetivamente vinculante, de imperativos práticos ou categóricos, ou então valores absolutos e incondicionados. Como resultado, Schopenhauer e Nietzsche tematizam as noções de consciência e sentimento moral por meio de conceitos que, se por um lado remetem às éticas do caráter, por outro diferem delas em virtude das respectivas posturas filosóficas disruptivas em relação à tradição da filosofia moral ocidental.

Quanto a esses dois pensadores por último mencionados, o presente trabalho tem o objetivo de expor algumas das linhas mestras de sua ética, com fulcro em dois núcleos ou eixos problemáticos: a questão da possibilidade e legitimidade de imputação de 
juízos morais, ou de julgamentos acerca do valor moral das ações; e o topos clássico da sittliche Weltordnung (ordenação ética ou significação moral do mundo). A razão de ser dessa escolha, consciente de seus limites, é que a fortuna crítica de ambos, em termos da relevância e atualidade das respectivas contribuições para o enfrentamento de dilemas éticos do mundo contemporâneo, pode ser melhor apreendida a partir desses vetores.

Numa passagem de $O$ Crepúsculo dos Ídolos especialmente ilustrativa da tarefa de transvaloração de todos os valores, Nietzsche alveja um dos bastiões mais bem guardados da filosofia e da moral ocidental: a tese de acordo com a qual, na ausência de liberdade da vontade (entendida como liberum arbitrium indiffentiae) não pode haver imputação das ações a seus agentes, posto que justamente na pressuposição da mesma reside o fundamento da responsabilidade. De acordo com a interpretação de Nietzsche, nossa tradição cultural fundamentou os juízos sobre o valor moral e sobre a possibilidade de legítima imputação jurídica das ações precisamente na liberdade do arbítrio.

Era sobre esse alicerce que ela apoiava, em derradeira instância, todo edifício da inculpação.

Onde quer que responsabilidades sejam procuradas, aí costuma estar em ação o instinto de querer punir e julgar. Despiu-se o vir-a-ser de sua inocência, quando se reconduziram os diversos modos de ser à vontade, às intenções, aos atos de responsabilidade. A doutrina da vontade é inventada essencialmente em função das punições, isto é, em função do querer-estabelecer-a-culpa... Os homens foram pensados como 'livres' para que pudessem ser julgados e punidos - para que pudessem ser culpados ${ }^{1}$.

Nesse ponto extremo, encontramos a artéria vital da crítica nietzschiana da moral e da cultura. A doutrina da imputação foi inventada em vista de poder estabelecer, legitimar e justificar a culpa, e com ela a justiça como vingança, como retribuição, o ressentimento e seus aparentados. É necessário pensar-se como livre para poder ser considerado digno de ser culpado. Toda crítica do ressentimento e da consciência de culpa, a interpretação global da existência a partir da perspectiva da transgressão e da expiação, tem aqui seu reduto mais bem defendido. 0 imoralismo de Nietzsche, já expresso no aforismo 125 de A Gaia Ciência, na célebre alegoria do homem louco, que anuncia na praça do mercado a morte de Deus, tem nisso seu centro de gravidade: pode

${ }^{1}$ NIETZSCHE, F. Crepúsculo dos Ídolos, Os Quatro Grandes Erros, p. 49.

Ser e sentido: o paradoxo do sofrimento 
o homem civilizado viver sem o sentimento de culpa? Ora, é verdade que Deus está morto, e se com a morte de Deus fica abolida a perspectiva transcendente do absoluto e do incondicionado; se é verdade que só em relação a essa perspectiva de interpretação da vida a culpa pode ser justificada; se é verdade ainda que todos nós - os epígonos e herdeiros da modernidade política e cultural -, todos nós, somos seus assassinos; então não nos restaria outra escolha: teríamos que nos colocar à altura da compreensão tanto de nosso próprio feito quanto de seu sentido, alcance e consequências.

O mais forte e mais sagrado que o mundo até então possuíra sangrou inteiro sob os nossos punhais - quem nos limpará este sangue? Com que água poderíamos nos lavar? Que ritos expiatórios, que jogos sagrados teremos de inventar? A grandeza desse ato não é demasiado grande para nós? Não deveríamos nós mesmos nos tornar deuses, para ao menos parecer dignos dele?

Viver para além de Bem e Mal, no horizonte infinito de uma completa inocência do vir-a-ser é uma das maneiras de compreender os temas da tragédia e da completa auto-determinação como superação do humano em Nietzsche.

Pode-se afirmar que, em considerável medida, a medula da oposição de Friedrich Nietzsche à ética de Arthur Schopenhauer encontra-se na questão filosófica da possibilidade e do fundamento da imputação, na justificativa para a atribuição legítima de valor moral às ações humanas. Essa possibilidade de legitimação teórica da culpabilidade prende-se essencialmente, como já mencionado acima, à questão da significação ética do mundo (sittliche Weltordnung, moralische Weltbedeutung), que, para Schopenhauer, constitui o ponto culminante de toda verdadeira filosofia, cuja negligência ele reputa como radicalmente funesta:

Que o mundo tenha uma mera significação física, nenhuma significação moral, é a maior, a própria e mais perniciosa perversidade da mente, o erro fundamental; ela é, no fundo, aquilo que a fé personificou no Anticristo $^{3}$.

Um decidido pessimismo a respeito do valor global da existência, uma concepção trágica da vida, bem como um profundo concernimento pelo drama existencial da

2 NIETZSCHE, F. A Gaia Ciência, 125, p. 148.

${ }^{3}$ SCHOPENHAUER, A. P/P, Kapitel 8, § 109, p. 238.

Ser e sentido: o paradoxo do sofrimento 
finitude, do sentido da dor da morte, assim como a negação compartilhada da validade das leis morais universais, ou de deveres e valores dos quais possam ser derivadas normas racionais práticas dotadas de força vinculante para seres racionais em geral constituem o solo filosófico sobre o qual abre-se uma verdadeira encruzilhada que separa e opõe os caminhos da ética de Schopenhauer e Nietzsche.

Se há uma dimensão de universalidade ética em Schopenhauer, então seu fundamento filosófico só pode remontar ao sentimento de compaixão; em Nietzsche, uma estilística da existência, de base existencial, substitui os projetos éticos de pretensa validade universal; a justificação estética da existência humana no mundo é a perspectiva ética como forma de vida, em Nietzsche, cuja radical contingência e facticidade não pode ser resgatada nem mesmo por meio do recurso a um sentimento de compaixão pela miséria humana e pelas dores do mundo. No aforismo 290 de A Gaia Ciência, Nietzsche encerra essa concepção numa fórmula programática:

Uma coisa é necessária. - 'Dar estilo' a seu caráter - uma arte grande e rara! É praticada por quem avista tudo o que sua natureza tem de forças e fraquezas e o ajusta a um plano artístico, até que cada uma delas aparece como arte e razão, e também a fraqueza delicia o olhar ${ }^{4}$.

\section{A fundamentação da moral em Schopenhauer}

Na filosofia de Arthur Schopenhauer, cada ser humano individual, na medida em que constitui o supremo grau de objetivação fenomenal da vontade, tem (é) um caráter absolutamente singular. É nesse sentido que se deve entender a variante schopenhaueriana da noção de pessoa, embora não se deva perder de vista que em todos os seres humanos manifeste-se também, predominantemente, o genérico caráter da espécie. Com base nisso, a diferença dos caracteres humanos pode ser compreendida e explicada analogicamente pela diferença entre espécies naturais; estas são, para Schopenhauer, o correspondente das ideias platônicas, os protótipos ou essências inteligíveis, que servem de modelos para as espécies naturais, com as respectivas multiplicidades de indivíduos, bem como para as forças da natureza, que são também irredutíveis aos seus fenômenos individuais.

Se as ideias correspondem às espécies, de modo que os entes singulares 
consistiriam em instanciações fenomênicas desses protótipos inteligíveis, que consistem no primeiro grau de objetivação da vontade (objetidades, à diferença de objetivações, que constituem uma derivação de segundo grau), então a verdadeira compreensão da essência de todo ente particular só seria alcançada a partir da intelecção de sua ideia; porém, no caso do ser humano, pode-se constatar um movimento explicativo em sentido inverso e complementar, de tipo analógico, mas que subverte inteiramente a mencionada relação. $\mathrm{O}$ atributo essencial e constante dos indivíduos humanos, o elemento que neles podemos denominar, com toda propriedade, caráter inteligível, embora remeta à identidade genérica das notas próprias, que diferenciam a espécie humana dentre as demais espécies animais, esse caráter inteligível, ao contrário do que ocorre com os outros animais, mesmo os que situam nos níveis mais elevados da escala zoológica, não deriva primacialmente da ideia de espécie humana.

Porque o ser humano é o ente natural que exibe e concretiza o grau mais elevado e complexo de objetidade da vontade, o caráter é absolutamente singular: mesmo gêmeos idênticos, nascidos e criados no mesmo ambiente, são personalidades inteiramente distintas e não intercambiáveis. No ser humano, portanto, podemos apreender a Ideia como ato originário da Vontade Metafísica em toda sua clareza, como ato livre e absolutamente contingente. Sendo assim, todas as ideias que consistem em modelos das espécies naturais e das forças cósmicas, e que organizam todos os graus de objetivação da vontade no universo, e, com isso, constituem a essência de que os seres individuais e fenomênicos são mera aparência, essas ideias têm algo em comum, e revelam esse traço próprio do caráter inteligível humano; desse modo, portanto, deixamse apreender adequadamente como sendo também expressões originariamente livres da vontade, objetivando-se nos exemplares que constituem as espécies da naturais, com suas respectivas individualidades, com seus peculiares modos de efetivação e ação, de acordo com a determinação da causalidade natural, cuja fórmula universal é o princípio de razão suficiente.

A forma própria à espécie animal corresponde à ideia, considerada como ato da vontade fora das formas da representação, portanto intemporal, e de uma indivisível unidade. Aliás, é esse desdobramento da ideia no indivíduo vivo que fará aparecer a finalidade interna de cada organismo. Sabemos, enfim, que, ao menos no homem, aparece um caráter individual ao lado do caráter empírico imutável, inato, o qual corresponde a um caráter inteligível, quer dizer, a uma ideia. 
Alcançamos, enfim, a mais alta objetidade da vontade de viver, e sem dúvida a mais clara, nesse sentido que a ideia deixa-se conhecer aí como ato primitivo da vontade, ou ainda como liberdade, ao encontro da necessidade fenomenal. Não é somente a ideia do indivíduo humano que poderia ser dita 'caráter inteligível', mas finalmente toda ideia na natureza inorgânica e orgânica, em todos os graus da objetivação. Metafisicamente, o macrocosmo se esclarece a partir do microcosmo humano. A hierarquia irredutível das ideias revela ainda uma vez a cegueira de uma redução materialista e a impossibilidade de uma explicação mecanicista generalizada 5 .

Também nesse plano de consideração do mundo, o macrocosmo se deixaria compreender à luz do microcosmo humano, tendo a pessoa, portanto, o mesmo estatuto filosófico do caráter empírico: a pessoa singular é a manifestação ou fenômeno do caráter inteligível. Por essa razão, a liberdade nunca pode ser situada na pessoa, pois, como todo fenômeno natural, esta obedece à inexorável lei de causalidade. A pessoa:

[...]nunca é livre, embora ela seja o aparecer (Erscheinung) de uma vontade livre: pois é justamente desse livre querer que ela é já uma manifestação determinada e, na medida em que esta manifestação ingressa na forma de todo objeto - o princípio de razão suficiente -, ela desenvolve, no entanto, a unidade daquela vontade na multiplicidade das ações; estas, entretanto, em virtude da unidade em-si atemporal daquele querer, apresentam-se com a regularidade de uma força da natureza ${ }^{6}$.

Se as ideias platônicas e das forças naturais não podem ser consideradas múltiplas - na medida em que são únicas, embora se refratem, na empiria, em indivíduos ou fenômenos múltiplos, que são suas cópias ou manifestações, submetidas, estas sim, a espaço, tempo e causalidade -; assim também se passa com o caráter inteligível humano, valendo para ele também que e sua refração espaço-temporal nas múltiplas ações de um homem individual, totalizadas na natureza por seu caráter empírico, também estão submetidas ao princípio de razão. Trata-se, portanto, da mesma relação entre ideias e forças da natureza, por um lado, e realidade empírica e fenômenos naturais, por outro lado; ora, em Schopenhauer, uma vez que a essência metafísica do mundo é Vontade, um impulso cego e irracional, aquela relação sempre tem de deixar um resíduo de incompreensibilidade. Desse modo, como base para toda explicação científica e causal da natureza, há que se pressupor uma força original, a que só temos acesso por seus

${ }^{5}$ LEFRANC, J. Compreender Schopenhauer, p. 145.

${ }^{6}$ SCHOPENHAUER, A. WWV I, IV, § 55, p. 398.

Ser e sentido: o paradoxo do sofrimento 
fenômenos, necessariamente encadeados segundo a relação de causa e efeito, uma relação que constitui a forma universal do entendimento humano, e que, ela própria, é inexplicável.

Assim, uma explicação desse gênero, qualquer que ele seja, jamais explica tudo, mas deixa sempre, em última análise, qualquer coisa de inexplicável. Isso é o que constatamos a cada instante na física e na química. A explicação dos fenômenos, quer dizer, dos efeitos, assim como os raciocínios que remetem esses fenômenos a sua origem última, pressupõem sempre a existência de certas forças naturais. Uma força natural, considerada em si mesma, não está submetida a nenhuma explicação, mas ela é o princípio de toda explicação. Do mesmo modo, ela não está submetida, nela mesma, a nenhuma causalidade, mas ela é precisamente o que dá a cada causa a causalidade, quer dizer, a possibilidade de produzir seu efeito. Ela é o substrato comum de todos os efeitos dessa espécie e está presente em cada um deles ${ }^{7}$.

Em analogia com esse substrato comum, como manifestações de nosso caráter empírico, as ações humanas remetem a uma base que não pode ser objeto de explicação, pois seu fundamento derradeiro 'dá-se' fora das coordenadas de tempo, espaço e causalidade, mas no plano transcendental do caráter inteligível. Este deve ser entendido como um ato livre e a-temporal da vontade metafísica, a que se pode, justificadamente, predicar liberdade em sentido metafísico, compatível com uma radical negação, no âmbito empírico, do livre arbítrio de indiferença. Trata-se de um proto-ato da vontade, análogo ao que constitui o caráter inteligível da espécie, desta feita como feito único em cada objetivação singular, sob a forma de um caráter (constância) inteligível. Ora, sendo a 'coisa em si' schopenhaueriana a Vontade metafísica, o caráter inteligível seria o ato originário de seu ingresso no domínio da objetivação, mais precisamente como objetivação imediata, ou, no léxico schopenhaueriano, objetidade. Desse modo, considerado do ponto de vista da Vontade, o ser é ato do querer - a existência é feito da vontade, somos o que queremos, ainda que não possamos querer o que somos.

E, o que é mais, como ato livre ele pode e deve, por conseguinte, ser imputável à vontade, já que todo ente individuado não é, em essência, outra coisa que a própria Vontade, razão pela qual o ato que constitui o caráter inteligível, como ato de vontade, pode ser imputado a esta; de outro modo, todo ser humano é o que quer ser.

7 SCHOPENHAUER, A. F/L. In: SW, Band III, p. 566. 
De acordo com isso, o conflito sobre a liberdade do fazer individual, sobre o liberum arbitrium indifferentiae, gira propriamente em torno da questão sobre se a vontade se encontra no tempo ou não. Se ela é a coisa-em-si fora do tempo e de toda forma do princípio de razão suficiente, como torna necessário tanto a doutrina de Kant como toda minha apresentação, então não apenas o indivíduo, em idêntica condição tem de agir sempre do mesmo modo, e não apenas cada má ação tem de ser a firma garantia para inúmeras outras que ele tem de perfazer e não pode deixar, porém deixar-se-ia também calcular, como diz Kant, o comportamento do homem no futuro como uma eclipse do sol ou da lua, desde que fossem completamente dados o caráter empírico e os motivos. Assim como a natureza é consequente, assim também é o caráter8.

Com base nisso, podemos perceber que a recusa por Schopenhauer de um liberum arbitrium indifferentiae, coincide com a postulação de uma liberdade transcendental da vontade metafísica, baseada numa interpretação sui generis do conceito de caráter inteligível de Kant. Caráter inteligível, ideias e forças naturais são expressões imediatas da Vontade metafísica, o estágio inicial da objetivação que constitui o mundo fenomênico: a objetidade da representação não submetida ao princípio de razão, à qual podemos ter acesso. Com efeito, de acordo com Schopenhauer, se o em-si do mundo é Vontade, então o caráter inteligível é o correlato do Ser, na oposição Ser versus Vir-a-Ser; o caráter sensível, por sua vez, é o correlato do Devir; do ponto de vista ontológico, o caráter inteligível é correspondente, pois, à essência (esse), enquanto que o caráter empírico é o correspondente à existência (operari), o mesmo ocorrendo na oposição entre o real e o aparente, coisa em si e fenômeno, inteligível e sensível.

Por meio desse filosofema, Schopenhauer inverte o curso da tradição filosófica que defende a liberdade do arbítrio, ao escrever:

De acordo com a tese tradicional, o homem teria apenas que refletir "como ele preferencialmente gostaria de ser, e ele assim o seria: esta é sua liberdade da vontade. Ela consiste propriamente em que o homem é sua própria obra, à luz do conhecimento. Eu digo, ao contrário: ele é sua própria obra antes de todo conhecimento, e este é meramente acrescentado para iluminar isso. Por isso, ele não pode resolver ser tal ou tal, nem ainda pode ele tornar-se um outro; mas ele é um de uma vez por todas, e conhece sucessivamente o que ele é. De acordo com aquela (tradição, OGJ.) ele quer o que ele conhece; para mim ele conhece o que ele quer' ${ }^{9}$.

${ }^{8}$ SCHOPENHAUER, A. WWV I, IV, § 55; op. cit, p. 402.

${ }^{9}$ Idem, p. 403.

Ser e sentido: o paradoxo do sofrimento 
Se, com Schopenhauer, não podemos falar em lei moral, em dever ou obrigação dela decorrente como fundamento da ética, nem por causa disso podemos prescindir dos conceitos éticos cardinais como responsabilidade e consciência moral, ainda que num mundo sem Deus, sem fundamento racional, no qual meu ser é ato da vontade que me constitui como esse caráter, suscetível, em maior ou menos medida, ao cortejo dos motivos que, atuando sobre sua estrutura, determinarão meus atos empíricos de vontade.

Como é fácil perceber, esse caminho conduz a que não temos mais que buscar a obra de nossa liberdade, como o faz o ponto de vista comum, em nossas ações singulares, mas no próprio todo de essência e existência do homem, que deve ser pensado como um feito livre (freie Tat), que só para a faculdade de conhecimento, ligada a tempo, espaço e causalidade, se apresenta como uma multiplicidade e diferença de ações. No entanto, em virtude da unidade originária daquilo que nelas se apresenta, têm de portar todas exatamente o mesmo caráter e, por causa disso, aparecem como rigorosamente necessitadas pelos respectivos motivos, pelos quais são provocadas e singularmente determinadas ${ }^{10}$.

A consciência moral não enuncia mais a voz de Deus no recôndito da alma, mas é formada a partir de uma curiosa química entre elementos pouco provectos, como temor, eudemonia, preconceito, vaidade, hábito, superstição. Como se pode facilmente notar, essa composição química contrasta com a acepção tradicional da consciência moral, especialmente com o conceito de dignidade.

A mim parece que o conceito de dignidade aplicado a um ser tão pecaminoso, quanto à vontade, tão limitado quanto ao espírito, tão vulnerável e perecível quanto ao corpo, tal como é o homem, só pode ser efeito em sentido irônico: Quid superbit homo? cujus conceptio culpa, Nasci poena, labor vita, necesse mori! [De que se jacta o homem? Uma vez que já sua concepção é culpa, seu nascimento, castigo, sua vida, trabalho, e sua morte inevitável!] Por causa disso, ao invés da mencionada fórmula do princípio moral kantiano, eu gostaria de estabelecer a seguinte: para todo homem com quem entramos em relação, não empreendamos uma avaliação objetiva do mesmo, de acordo com o valor e a dignidade; não tomemos em consideração a ruindade de sua vontade, a limitação de seu entendimento, e a perversão de seus conceitos; pois a primeira coisa facilmente poderia

10 SCHOPENHAUER, A. F/L. In: SW, Band III, p. 622. 
despertar ódio contra ele, a última desprezo; ao invés disso, tenhamos em vista apenas seus sofrimentos, sua carência, sua angústia, suas dores: - então poderemos nos sentir sempre aparentados com ele, sentir simpatia para com ele; e, ao invés daquele ódio ou desprezo, deixar aflorar somente o ágape [amor], ao qual o Evangelho conclama. Para não deixar que emerja contra ele nenhum ódio, nenhum desprezo, não é a investigação de sua pretensa dignidade o ponto de vista adequado, mas, ao contrário, somente aquele da compaixão ${ }^{11}$.

Percebemos, pois, que a versão schopenhaueriana do caráter inteligível torna possível um resgate da consciência moral, nas condições próprias do sistema do pensamento único: ela continua a ser pensada como o aguilhão moral voltado contra o esse de nosso operari, instalado em nosso ser, que se manifesta em nossas volições e ações, como expressões autênticas daquilo que singular e facticamente somos, daquilo que nos distingue de todo e qualquer outro. A consciência e o sentimento moral se originam a partir de nossas ações, como o conhecimento e aproximação paulatina do íntimo de nosso si-próprio, da estrutura de nosso caráter; por causa disso, a voz da consciência só pode ser ouvida depois das ações, e, ainda assim, somente ajudada pela reflexão sobre as mesmas, em comparação com casos anteriores, que ela já examinou, e em prognóstico a respeito daquilo que, em retrospectiva, pode ser razoavelmente esperado.

Com base nisso, é o esse que, tal como em Spinoza, é propriamente inculpado pela consciência moral; ele o é, todavia, só por ocasião do operari. "Uma vez que somos conscientes da liberdade só por meio da responsabilidade, então onde está a segunda, também tem de estar a primeira: portanto, no esse"12. Depois dessa depuração da consciência moral de seus arroubos teológico-metafísicos, suas vozes adquirem novo tom e compreensibilidade: o remorso passa a ser entendido como um erro de cálculo, ou um engano estratégico: arrependemo-nos porque usamos meios inadequados pra alcançar os fins pretendidos, que continuamos a desejar. Já a Gewissensangst (angústia de consciência) é a voz que corresponde à percepção consciente de que nossa essência íntima, o caráter constante progressivamente trazido à luz por nossas ações, ao longo de nossa história de vida, é o que é, e é inalterável.

Todo homem age de acordo com aquilo que ele é; de acordo com isso, a cada vez a ação necessária é determinada no caso individual somente

11 SCHOPENHAUER, A. Preisschrift über die Grundlage der Moral, S. 246; S. 220 f.

12 SCHOPENHAUER, A. F/L. In: SW, Band III, par. 10, op. cit. p. 708.

Ser e sentido: o paradoxo do sofrimento 
pelos motivos. A liberdade, que por isso não pode ser encontrada no operari, tem de encontrar-se no esse. É um erro fundamental um ystéron próteron [confusão entre causa e consequência, antecedente e consequente] de todos os tempos atribuir ao operari a necessidade que compete ao esse. Inversamente: unicamente no esse reside a liberdade; dele, porém, assim como dos motivos segue-se necessariamente o operari: é naquilo que fazemos que conhecemos o que somos. Sobre isso, e não sobre o libero arbitrio indifferentiae baseia-se a consciência da responsabilidade e a tendência moral da vida ${ }^{13}$.

Isso significa que, para Schopenhauer, em todo tempo, o homem só faz aquilo que ele quer; isso, porém, ele o faz necessariamente. A razão é que ele já é aquilo que ele quer: pois daquilo que ele é, segue-se necessariamente tudo aquilo que ele, a cada vez, faz. No plano dos julgamentos morais sobre o valor das ações, a base do juízo só pode ser encontrada na natureza do agente, e na força de pressão dos motivos e contra-motivos, em cada situação concreta de ação, espaço-temporalmente circunscrita, exercem sobre a suscetibilidade do caráter do agente aos diferentes tipos de móbiles ou motivações. Ora, o que move principalmente a vontade de um agente é o bem-estar ou o mal-estar, tomados no sentido mais amplo da palavra, como também inversamente bem-estar e mal-estar significam 'de acordo ou contra uma vontade'. Portanto, todo motivo tem de se referir bem-estar e ao mal-estar; consequentemente toda ação refere-se a um ser suscetível de bem-estar ou mal-estar como seu fim último.

Uma vez que o agente de que aqui se trata ou o próprio agente, ou um outro ser, que portanto participa da ação passivamente, pois ela acontece para seu dano ou para seu proveito e alegria, então toda ação tem como finalidade o bem estar ou a cessação do mal estar, seja do agente, seja de outrem passivamente envolvido na ação do primeiro. Ora, toda ação cujo fim último é o bem-estar e o mal-estar do próprio agente é uma ação egoísta; e o mesmo vale igualmente para o deixar-de-fazer, para as omissões de tais ações, para as quais existem motivos e contra motivos.

Para Schopenhauer Egoísmo e Valor Moral simplesmente excluem-se um ao outro. Se uma ação tiver um fim egoísta como um motivo, então ela não pode ter nenhum valor moral. Deva uma ação ter valor moral, então um fim egoísta não pode ser seu motivo imediato ou longínquo. Por conseguinte, a significação moral de uma ação só pode estar na sua relação com outros. Só com referência a estes é que ela pode ter valor moral ou

13 SCHOPENHAUER, A. F/L. In: SW, Band III. p. 622. 
ser condenável moralmente e, assim, ser uma ação de justiça e caridade, como também o oposto de ambas. Isso significa que toda ação provida de valor moral é altruísta, e a possibilidade de ações altruístas é o desprendimento de si, a restrição ou negação da primazia do próprio ego, cujo fundamento metafísico, embora não transcendente, é encontrado por Schopenhauer no sentimento de compaixão ${ }^{14}$.

Tudo depende do que uma pessoa é. Aquilo que ela faz resultará espontaneamente do que ela é, como um corolário necessário. Isso significa apenas que sua atuação é a pura exteriorização da essência mais própria de seu Si-Mesmo (Selbst). Todo ente da natureza sentiria isso, se pudesse sentir. Com isso, não fica suprimida a liberdade, ela é apenas deslocada para frente, a saber: transposta do âmbito das ações individuais (no qual ela comprovadamente não pode ser encontrada), para um região superior, porém não tão facilmente acessível ao nosso conhecimento, ou seja, a liberdade é transcendental. Este é então também o sentido no qual Schopenhauer desejaria que fosse compreendido a sentença de Malebranche sob cuja égide foi composta a dissertação Sobre a liberdade da vontade: la liberté est um mystère.

Por essas razões, um dos resultados mais eloquentes da ética de Schopenhauer é o pessimismo teórico que anima seu juízo a respeito do sentido e do valor das teodiceias:

Não posso conferir à Teodiceia, a esse largo desdobramento do otimismo nenhum outro mérito além de ter dado ensejo, mais tarde, ao imortal Cândido do grande Voltaire; por cujo meio, com efeito, recebeu uma comprovação inesperada a desculpa capenga e tão frequentemente repetida por Leibniz para os males do mundo, a saber que o mau por vezes conduz ao bom. Já por meio do nome de seu herói, Voltaire indica que só é necessário sinceridade para reconhecer o contrário do otimismo. Efetivamente, sobre esse palco dos pecados, do sofrimento e da morte o otimismo faz uma figura uma tão peculiar, que deveríamos tomá-lo por ironia, se não tivéssemos uma explicação suficiente de sua origem secreta na fonte, tão deliciosamente descoberta por Hume (a saber, adulação hipócrita, com ofensiva confiança em seu sucesso) ${ }^{15}$.

O otimismo seria, no fundo, a injustificada auto glorificação da vontade de viver, sua reflexão satisfeita e complacente na face sofredora de suas criaturas, razão pela qual o otimismo metafísico não constitui apenas uma doutrina falsa, mas também perniciosa e indecorosa, de acordo com o filósofo. Pois ele nos apresenta a vida como um estado desejável, e a felicidade como bem supremo da vida humana. Nossa vida, porém,

\footnotetext{
14 Para toda essa passagem, cf. SCHOPENHAUER, A. Sobre o fundamento da moral, § 16. 15 SCHOPENHAUER, A. WWV II, Kap. 46. In: SW, Band II, p. 733. 
[...] é igual a uma conta que recebemos para ser paga em autênticos centavos de cobre, com os quais, todavia, temos de liquidá-la: eles são os dias; a conta é a morte. Pois, finalmente, o tempo anuncia a sentença da natureza sobre o valor de todos os entes que nela aparecem, ao aniquilálos: e com direito: pois tudo o que surge é digno (ist werth) de perecer; por isso seria melhor que nada tivesse surgido. Dessa maneira, a velhice e a morte, para as quais toda vida se apressura, são o resultante juízo condenatório sobre a vontade de viver, brotado das mãos da própria natureza, juízo que afirma que essa vida é um anseio que tem de frustrar a si próprio"16.

Prefigurando, antes mesmo de qualquer esboço de formulação sistemática, o vetor decididamente prático que seria assumido por sua filosofia, Arthur Schopenhauer experimentou, desde muito cedo, no plano pessoal e existencial, um concernimento intenso e profundo pelos sofrimentos do mundo:

Já o jovem de 16 anos foi profundamente atingido pela multiplicidade das dores humanas e pelos abismos da maldade humana. A esse respeito, a visita à infame a prisão de Bagno, em Toulon, que reunia em seis mil galés um quadro assustador da miséria da humanidade, representou um ponto de culminância de sua vida. A experiência do sofrimento no mundo foi o impulso decisivo para que Schopenhauer se voltasse para a filosofia. A estadia de várias semanas num internato em Winbledon fez despertar em Schopenhauer uma decidida aversão contra a carolice e a religiosidade cristalizada em rituais ${ }^{17}$.

Por causa disso, escreve já o filósofo maduro,

Mille piacer' non vagliono un tormento. Pois que milhares tenham vivido em prazer e delícias jamais suprimiria a angústia e o martírio de morte de uma única pessoa; e, do mesmo modo, meu bem estar atual não faz desaparecer meus sofrimentos anteriores. Por causa disso, mesmo que o mal existente no mundo fosse cem menor do que é, ainda assim, todavia, a mera existência teria dele o suficiente para fundamentar uma verdade que, de maneiras diferentes, só se deixa formular de modo indireto, a saber, que não podemos nos alegrar quanto à existência do mundo, antes pelo contrário, temos que nos afligir ${ }^{18}$.

16 Ibidem, p. 733.

17 SALAQUARDA, J. Arthur Schopenhauer (d1788-1860). Mimeo, p. 2. Na nota 2 desse mesma página podemos ler: "Perante Wieland Schopenhauer (como estudante) expressou em 1811: 'A vida é uma coisa infeliz, eu prescrevi a mim mesmo refletir sobre ela. (Gespräch, 22)”. Esse mesmo texto foi posteriormente republicado por Matthias Kossler e Barbara Salaquarda: Die Deutung der Welt. Jörg Salaquardas Schriften zu Arthur Schopenhauer. Würzburg: Könnigshausen \& Neumann, 2007, p. 59-66. Infelizmente, o trecho citado não consta da publicação.

18 SCHOPENHAUER, A. WWV II, Kap. 46. In: SW. Band II, p. 733. 
Numa perspectiva inversa à glorificação da vontade de viver pelas diferentes teses do otimismo moral, Schopenhauer estabelecerá como verdade da ética sua soteriologia filosófica, a redenção pela auto negação da vontade. Enquanto as éticas otimistas reputam justa a pretensão humana à felicidade e gozo, tanto assim que, no caso em que não lhe sejam proporcionados, justificam a pretensão de acreditar que algo injusto acontece ao homem, qual seja, que a uma vida, nessas circunstâncias, faltaria a finalidade de sua existência, Schopenhauer considera mais verdadeiro e honesto conceber o trabalho, a necessidade de renúncia, a fadiga, a penúria, a frustração e o sofrimento, coroados pela morte, como a autêntica finalidade de nossa vida, tal como o fazem o Bramanismo, o Budismo e também aquele ele toma pelo autêntico Cristianismo, tendo como resultado a doutrina da negação da vontade de viver, a libertação da roda de Ixion e do inferno da vontade.

Muito longe de portar o caráter de um presente (Geschenck), a existência humana tem inteiramente o caráter de uma dívida/culpa (Schuld) contraída. A exigência de pagamento desta aparece na forma daquela existência colocada em meio de carências urgentes, penosos desejos, e infinita miséria. Em regra, todo o tempo de vida é empregado no pagamento dessa dívida: com isso, todavia, são pagos apenas os juros. 0 pagamento do capital acontece por meio da morte. - E quando foi contraída essa dívida/culpa? - no ato da geração -19.

Budista em solo europeu, Schopenhauer se propõe a mergulhar o olhar nos abismos da existência humana: quanto mais fundo olhamos na vida, mais fundo enxergamos nela o sofrimento - pois viver é sofrer. Esse europeu compartilhava as quatro nobres verdades do Budismo: Tudo é sofrimento e sofredor. Existe uma origem, um surgimento do sofrimento. Existe uma cessação do sofrimento. Existe um caminho que leva à cessação do sofrimento. E Schopenhauer sabia também que nenhuma teodiceia é capaz de resgatar o infortúnio de um único sofrimento, que nenhuma Providência governa o curso do mundo, nenhum intelecto supremo, dirigindo uma vontade infinitamente boa, pode ser considerado honestamente como princípio de produção, causa eficiente ou fundamento de inteligibilidade do universo e do progresso moral do gênero humano na história.

Para Schopenhauer, a essência metafísica do universo é vontade; e vontade é 
sinônimo de vontade de vida (Wille zum Leben), mas este é um impulso cego, irracional, portanto desprovido de finalidade e justificação teórica ou moral. Em virtude de seu princípio, o mundo não pode deixar de refletir, na face eternamente sofredora de todas as suas objetivações, a contradição interna da vontade: fratura irreparável, falta permanente, insatisfação eterna, o inútil padecimento de Sísifo, a autofagia do querer insaciável. No entanto, a tese da liberdade inteligível arranca do desespero absoluto a filosofia de Schopenhauer, e, por uma imponderável magia dos extremos, transfigura seu pessimismo teórico em otimismo prático. A âncora de salvação é a tese do merecimento: todo sofrimento é merecido, porque pode ser imputado ao próprio ser do sofredor.

Se quisermos medir o grau de culpa com a qual nossa existência é lastreada, olhemos então o sofrimento que a ela encontra-se ligado. Toda grande dor, seja ela corporal ou espiritual, expressa aquilo que merecemos: pois ela não poderia nos atingir, se não a merecêssemos. Que também o Cristianismo enxerga a vida a essa mesma luz, é provado por uma passagem do comentário de Lutero a Gálatas, capítulo III, do qual disponho apenas em latim: 'Com nossos corpos e relacionamentos, somos todos, porém, submetidos ao demônio, e somos estrangeiros nesse mundo, do qual este é príncipe e Deus. Por isso, tudo se encontra sob seu domínio: o pão que comemos, a bebida que bebemos, a vestimenta que usamos, sim, até mesmo o ar e tudo aquilo por meio do que vivemos na carne.' Gritou-se sobre o caráter melancólico e desprovido de consolo de minha filosofia: isso reside meramente em que, ao invés de fabular como equivalente dos pecados um inferno futuro, eu demonstrei que onde jaz a culpa, neste mundo, aí também já existe algo de infernal: quem, no porém, quiser negar isso - este pode facilmente experimentá-lo alguma vez ${ }^{20}$.

O absurdo corajosamente visto, assumido, reconhecido, foi novamente conjurado pela taumaturgia ascética: todo sofrimento tem um sentido, haurido na significação moral do universo. 0 sofrimento é castigo pela injustiça da existência, pelo delito maior da geração. É nessa chave ascética que Schopenhauer interpreta o fragmento de Anaximandro como arauto da 'sittliche Weltordnung': "Pois donde a geração é para os seres, é para onde também a corrupção se gera segundo o necessário; pois concedem eles mesmos justiça e deferência uns aos outros pela injustiça, segundo a ordenação do tempo"21. De acordo com a tradução de Nietzsche: "De onde as coisas têm seu nascimento, ali também devem ir ao fundo, segundo a necessidade; pois têm de pagar

\footnotetext{
20 Ibidem, p. 743.

21 Anaximandro de Mileto. In: Os Pré-Socráticos, p. 22.

Ser e sentido: o paradoxo do sofrimento
} 
penitência e de ser julgadas por suas injustiças, conforme a ordem do tempo"22.

A existência é injustiça a ser expiada, por isso a única e autêntica libertação e redenção consiste na auto negação da vontade de viver, da qual o Nirvana budista é uma alegoria religiosa. 0 mundo é o que não deveria ser, a geração é injustiça e sacrilégio a que corresponde a justa retribuição do sofrimento e da morte, segundo a lógica da justiça eterna. A culpa pelo pecado maior não se encontra na responsabilidade por nossas ações, senão que o aguilhão da consciência moral nos aterroriza e tortura pelo que somos, o esse, não o operari, constitui o verdadeiro fundamento dos juízos de inculpação. Por meio desse tour de force Schopenhauer quebra a ponta, no plano ético, de seu pessimismo metafísico, convertendo sua filosofia senão em teodiceia pelo menos em soteriologia, cuja inspiração é a santidade e a ascese: jejum, castidade, obediência incondicional como quebrantamento definitivo da vontade. Nenhum motivo mais, nenhum combustível para o querer, mas quietivo, aniquilação da vontade, salto milagroso do volen ao nolen.

\section{Da genealogia da culpa ao resgate da inocência do vir-a-ser}

A meu ver, a lição mais importante que a psicologia dos ideais ascéticos praticada em Para a genealogia da moral nos transmite consiste num paradoxo: o ominoso não é a dor, mas a falta de sentido da dor; mais ainda, o intolerável é a dor da falta de sentido. A função dos ideais ascéticos, e a razão de ser de seu domínio prolongado na história da civilização ocidental consiste em que esses ideais provêm o narcótico para a dor da falta de sentido: a anestesia dessa dor insuportável é ministrada como 'vontade de nada', como negação da vontade de vida, ou melhor, como fictícia auto-negação da vontade. Fictícia porque a vontade de nada não é um nada de vontade, antes, de acordo com Nietzsche, uma vontade de ser outro, de estar n'outra parte, pois, no extremo limite, a vontade prefere ainda querer o nada a nada querer. É nesse limite crucial que Schopenhauer comparece na genealogia nietzscheana da lógica do delírio:

É justamente nesse mais íntimo reduto que Nietzsche se distingue essencialmente de Schopenhauer: pois o pessimismo do primeiro é dionisíaco, um pessimismo da força, que nega sem ressentimento, porque não interpreta o sofrimento e a morte como uma objeção contra a existência e contra o mundo. A existência é sofrimento, absurdo, 
portanto desprovido de todo sentido ou justificação moral. Não existe motivo, razão ou fundamento para o sofrimento, para a dor da falta de sentido, que é irresgatável - isso porque a liberdade inteligível é menos uma tese do que uma fábula, cuja plausibilidade é nutrida pelo erro da causalidade imaginária.

Para toda mentalidade sacerdotal e moralista, é preciso antes de tudo salvar a possibilidade de fundamentação dos juízos de imputação: há que existir um direito de julgar e de condenar, porque só com ela subsiste a possibilidade e a legitimidade da inculpação. A invenção doutrinária da liberdade da vontade tem na fundamentação da punição seu objetivo essencial; tratou-se sempre, para Nietzsche, de uma vontade, isto é, um querer descobrir culpados. A 'velha psicologia, a psicologia da vontade', tem como pressuposto que seus autores, ou seja, os sacerdotes à frente das velhas comunidades, quiseram criar e consagraram para si o direito de julgar e impor castigos - ou de reservar para Deus esse mesmo direito.

Nessas condições, pergunta-se Nietzsche: "qual pode ser a nossa doutrina? - Que ninguém dá ao ser humano suas características, nem Deus, nem a sociedade, nem seus pais e ancestrais, nem ele próprio ... Ninguém é responsável pelo fato de existir, por ser assim ou assado, por se achar nessas circunstâncias e nesse ambiente. A fatalidade de seu ser não pode ser destrinchada da fatalidade de tudo o que foi e será ... apenas isto é a grande libertação - somente com isso é novamente estabelecida a inocência do vir-aser..."23. A grande libertação, que restitui a inocência ao mundo do devir é a destruição implacável de todo direito (causa, razão, fundamento, legitimidade) para juízos de imputação de culpa.

É justamente nesse reduto derradeiro que Nietzsche se distingue essencialmente de Schopenhauer: seu pessimismo é dionisíaco, um pessimismo da força, porque nega sem ressentimento esse último bastião onde se refugia a fuga do medo, a dor do absurdo: a significação moral do universo. A existência é sofrimento, absurdo desprovido de todo sentido ou justificação moral. Não existe motivo, razão ou fundamento para o sofrimento, para a dor da falta de sentido, que é irresgatável - isso porque a liberdade inteligível é menos uma tese do que uma fábula, cuja plausibilidade é nutrida pelo erro da causalidade imaginária. Para toda mentalidade sacerdotal e moralista, é preciso antes de tudo salvar a possibilidade de fundamentação dos juízos de imputação: há que existir

${ }^{23}$ NIETZSCHE, F. Crepúsculo dos Ídolos, Os Quatro Grandes Erros, 8. p. 46.

Ser e sentido: o paradoxo do sofrimento 
um direito de julgar e de condenar, porque só com ela subsiste a possibilidade e a legitimidade da inculpação.

É assim que Crepúsculo dos Ídolos é, de fato, o anúncio mais efetivo da transformação desconcertante que aconteceu no final da vida lúcida de Nietzsche, a total revisão do estatuto da obra $O$ Anticristo. Como sabemos, este que seria o primeiro livro do programa de transvaloração de todos os valores acabou por ser identificado, pelo próprio filósofo, como a totalidade e cumprimento desse mesmo programa. $O$ Anticristo opera essencialmente uma implosão da tese filosófica da 'ordenação moral do mundo', com a qual, nessa obra paroxística, Nietzsche rompe em todos os frontes, principalmente naquele ocupado pela metafísica de Schopenhauer.

A libertação da vontade em relação ao ressentimento e a raiz ontológica de sua impotência constitui, para Nietzsche, a única Erlösung digna de uma filosofia que afirma incondicionalmente a vida. 0 cerne dessa atitude filosófica é exposto por ele no capítulo de Assim Falou Zaratustra, intitulado Da Redenção:

Assim se chama o ranger de dentes e a mais solitária tribulação da vontade. Impotente contra o que está feito - a vontade é um mau espectador para todo passado. A vontade não pode querer para trás: que não possa quebrantar o tempo nem a voracidade do tempo - essa é a mais solitária tribulação da vontade ... ' $O$ que foi, foi' - assim se chama a pedra que [a vontade) não pode remover. E assim ela remove pedras por raiva e por aversão, e vinga-se naquilo que não sente, do mesmo modo que ela, raiva e aversão ${ }^{24}$.

Assim, vingança é repugnância e aversão da vontade contra o tempo. Nisso consiste também o essencial da impotência vontade- na impossibilidade de confrontar-se não só com uma dimensão do tempo, com um período ao lado dos outros, mas de suportar aquilo o que o tempo essencialmente confere, dispensa e lega - o passar e o que passou; e, ao legá-lo, ele também já o congela na dimensão de um 'já era' inamovível. 0 tempo só doa e concede o que ele tem, e ele tem o que ele é - a saber, o decurso, o transcurso, a travessia.

A vingança é, para Nietzsche, a repugnância da vontade contra o tempo. Isso agora diz: A vingança é a repugnância da vontade contra o decorrer e seu decorrido, contra o tempo e o seu 'era'. A repugnância da vingança dirige-se contra o tempo à medida que deixa estar o decorrido ainda 
apenas enquanto passado, que se congela na rigidez desse algo definitivo... A repugnância da vingança permanece acorrentada a esse 'era'; assim como em todo ódio também se oculta a mais abissal dependência daquilo de que o ódio constantemente no fundo deseja tornar-se independente, o que, porém, nunca pode, e cada vez menos pode, enquanto odeia 25 .

A vontade, sem consciência da própria impotência, vinga-se naquilo contra o que se quebra sua força, contra o que sobre ela prevalece - o inamovível e definitivo, a que se acorrenta mais fortemente, a cada ato de vingança. A repugnância da vontade contra o fluir do tempo é a outra face da adversidade contra o imutável. Dessa repugnância nasce todo desejo de Além-do-Mundo, toda necessidade de consolo metafísico.

A extrema impotência da vontade consiste, para Nietzsche, em sua aversão para com o (passar do) tempo, com a transitividade do tempo - na experiência de não poder querer para trás. A essa experiência está ligado o sentimento de opressão, condenação, punição, sob a perspectiva do qual a existência inteira do homem e do mundo é vivida como culpa, a exigir castigo e expiação.

Como vingança, o ressentimento é um derivado dessa constelação afetiva: um sentir sempre de novo o mesmo - portanto, um sentimento reativo, repetição compulsiva da mesma indisposição crônica, reação contra uma dor, sem cessar reposta pela irreversibilidade do tempo. Ressentimento é o grilhão que mantém o ressentido cada vez mais aferrado em seu sofrimento, que atrai como um imã todas as suas outras vivências. O ressentimento é uma modalidade culpada, biliosa, envenenadora de ascetismo, porque ele adoece e destrói. É assim que o único vivido se repete como o retorno do mesmo, atando o ressentido à roda de Ixion do Karma-Samsara. 0 ressentimento - eterno retorno da vingança e seus aparentados -, é definitivamente, a impossibilidade de acesso ao verdadeiro Self, seja pela via budista da auto-iluminação, seja pela vivência sensível-corpórea da aceitação voluntária do destino, na modalidade

\footnotetext{
${ }^{25}$ HEIDEGGER, M. Que significa pensar? p. 182s. Was Heisst Denken? S. 106s: "Die Rache ist für Nietzsche des Willens Widerwille gegen die Zeit. Dies sagt jetzt: die Rache ist des Willens Widerwille gegen das Vergehen und sein Vergangenes, gegen die Zeit und ihr »Es war«. Der Widerwille geht nicht gegen das bloBe Vergehen, sondern gegen das Vergehen, insofern es das Vergangene nur noch vergangen sein, es in die Erstarrung dieses Endgtiltigen einfrieren lässt. Der Widerwille der Rache geht gegen die Zeit, insofern sie alles in das »Es war" aufgehen lässt und so das Gehen vergehen laässt. Der Widerwille der Rache richtet sich nicht gegen das blossee Gehen der Zeit, sondern gegen ihr Vergehenlassen des Gehens im Vergangenen, gegen das »Es war«. An dieses »Es war« bleibt der Widerwille der Rache gekettet; so wie auch in allem Hass sich die abgründigste Abhangigkeit von dem verbirgt, wovon der Hass sich im Grunde standig unabhangig machen mochte, was er jedoch nie kann und immer weniger kann, je mehr er hasst". 
nietzscheana do amor fati.

Esclarecer-se sobre o ressentimento é superar a aversão contra o tempo, contra o passar do tempo. É fazer uso de uma terapia budista como vitória sobre a incapacidade de esquecer e assimilar vivências negativas. Simulacro de medicação, a vingança só aprofunda a doença, envenena a ferida que finge curar. Saúde significa, em Nietzsche, uma autoterapia capaz de livrar alguém do venenoso sentimento do ressentido, pelo restabelecimento da força plástica de esquecimento.

0 verdadeiro pessimismo da força, o pessimismo dionisíaco, consiste na negação da significação ética do universo. Os gregos são modelo para Nietzsche porque, de acordo com sua interpretação do helenismo, a tragédia realiza a única justificação aceitável e legítima do sofrimento, da dor da falta de sentido - a justificação artística, extra moral. Justamente por causa disso, Nietzsche modifica, na segunda edição de $O$ nascimento da tragédia, o título que figurava na primeira edição. Ao invés de $O$ nascimento da tragédia a partir do espírito da música, o título passa a ser o seguinte: $O$ nascimento da tragédia: helenismo e pessimismo. Trata-se de um indício que dá sustentação à hipótese hermenêutica de acordo com a qual Nietzsche, desde sua obra inaugural, é um pensador anti-schopenhaueriano.

O sofrimento, mesmo o mais atroz, não é um motivo de resignação ou negação da vida, mas o caminho da vida que cria para além de si mesma. Dizer sim à vida sem acréscimo nem subtração, afirmar o sofrimento como elemento condicionador da felicidade, a destruição como caminho da vida, é o sentido mais profundo das celebrações dionisíacas das bacanais. Heráclito, não Anaximandro, é o arauto do pessimismo da força. Sobretudo por sua intransigente negação da tese metafísica acerca da significação ética do mundo, tal como a formula Schopenhauer, Nietzsche, sem hesitação, pode auto compreender-se e declarar-se: "em grego e não somente em grego, o Anticristo..."26

\section{Conclusão}

Para Max Horkheimer:

A doutrina pessimista de Schopenhauer é um consolo. Ao contrário da

${ }^{26}$ NIETZSCHE, F. Ecce Homo, Por que escrevo tão bons livros, p. 55.

Ser e sentido: o paradoxo do sofrimento 
mentalidade atual, sua metafísica proporciona a mais profunda fundamentação da moral, sem entrar em contradição com o conhecimento exato, sobretudo sem recorrer à representação de espíritos ultra mundanos, eternos, sejam eles bons ou maus. Schopenhauer fundamentou filosoficamente o amor ao próximo, sim, o amor à criatura, sem sequer tocar nas afirmações e preceitos confessionais, tornados hoje questionáveis - de modo que seu pensamento não é, de modo algum, tão pessimista como a absolutização da ciência ${ }^{27}$.

No que diz respeito à contribuição de Nietzsche, a percepção de Giorgio Agamben é exemplar:

A ética de nosso século se abre com a superação nietzschiana do
ressentimento. Contra a impotência da vontade em relação ao passado,
contra o espírito de vingança contra aquilo que irrevogavelmente foi e
não pode ser querido, Zaratustra ensina os homens a querer para trás, a
desejar que tudo se repita. A crítica da moral judaico cristã se perfaz, em
nosso século, em nome da capacidade de assumir integralmente o
passado, de libertar-se de uma vez por todas da culpa e da má
consciência ${ }^{28}$.

Relativamente a isso, a experiência de Auschwitz representa um limiar ético absolutamente inaudito; uma espécie de falência ou perempção da ética em nossa sociedade.

E isso, como observa Agamben, não porque o horror e a atrocidade dessa experiência sejam demasiado extremos para que se possa querer sua repetição; nem mesmo porque a perversão abissal de que Auschwitz é a prova que constitui também a refutação mais consistente da ética nietzschiana, uma vez que é sustentável levar o ressentimento ao ponto de simplesmente recusar o acontecido, assim como aconteceu, de modo que o que aconteceu torna-se infinitamente imperdoável.

Depois de Auschwitz, o problema ético mudou radicalmente: não se trata mais de vencer o espírito de vingança para assumir o passado, para querer que este retorne eternamente. Também não de manter firme, por meio do ressentimento, aquilo que não se pode humanamente tolerar, até o ponto de exigir a suspensão do tempo e do esquecimento, que com ele advém, como medida moral para tornar indelével as marcas daquilo que aconteceu no passado. Em nossos dias, num mundo onde a exceção tornou-

27 HOKHEIMER, M. Schopenhauers Denken. In: SALAQUARDA, J. (Ed). Schopenhauer, p. 232.

${ }^{28}$ AGAMBEM, G. Quel che resta di Auschwitz (Homo Sacer III), p. 92.

Ser e sentido: o paradoxo do sofrimento 
se a regra, talvez seja efetivamente verdadeiro o seguinte prognóstico:

Doravante, estamos diante de um ser além da aceitação e da recusa, do eterno passado e do eterno presente - um evento que eternamente retorna, mas que, justamente por isso, é absolutamente, eternamente inassumível. Além do bem e do mal não está a inocência do devir, mas uma vergonha não somente sem culpa, mas, por assim dizer, sem tempo ${ }^{29}$.

\section{Referências bibliográficas}

AGAMBEM, G. Quel che resta di Auschwitz (Homo Sacer III). Torino: Bollati Boringhieri, 1998. ANAXIMANDRO. Os Pré-Socráticos. São Paulo: Abril Cultural, 1973 (Coleção Os Pensadores). HEIDEGGER, M. Que significa pensar? Trad. Paulo R. Schneider. In: SCHNEIDER, P. R. O Outro Pensar. Ijuí: Editora Unijuí, 2005. Was heisst denken? In: Gesamtausgabe. Bd. 8. Frankfurt a.M: Vittorio Klostermann, 2002.

HORKHEIMER, M. Schopenhauers Denken. In: SALAQUARDA, J. (Ed). Schopenhauer. Darmstadt: Wissenschaftliche Buchgesellschaft, 1985.

LEFRANC, J. Compreender Schopenhauer. Paris: Armand Colin, 2002.

NIETZSCHE, F. A Gaia Ciência. Trad. Paulo César de Souza. São Paulo: Companhia das Letras, 2001.

. Assim falou Zaratustra. In: Sämtliche Werke. Kritische Studienausgabe in 15 Bänden (KSA). Bd. IV. Hrsg. Giorgio Colli und MazzinoMontinari. Berlin/New York: DTV \& Walter de Gruyter, 1999.

. Crepúsculo dos ídolos. Trad. Paulo César de Souza. São Paulo: Companhia das Letras, 2006. Ecce Homo. Trad. Paulo César de Souza. São Paulo: Companhia das Letras, 1995.

SCHOPENHAUER, A. Die Welt als Wille und Vorstellung I. In: Sämtliche Werke. Band I. Ed. Wolfgang Frhr. Von Löhneysen. Frankfurt a. M: Suhrkamp, 1986.

. Die Welt als Wille und Vostellung II. In: Sämtliche Werke. Band II. Ed. Wofgang Frhr. Von Löhneysen. Frankfurt a. M: Suhrkamp, 1986.

Parerga und Paralipomena. In: Sämtliche Werke. Band V. Ed. Wolfgang Frhr. Von Löhneysen. Framfurt a. M: Suhrkamp Verlag, 1986

Über die Freiheit des Willens. In: Sämtliche Werke. Band III. Ed. Wolfgang Frhr. Von Löhneysen. Frankfurt a. M: Suhrkamp, 1986.

Über die Grundlage der Moral. In: Werke in zehn Bd. Hrsg. v. Arthur Hübscher. Bd. VI.

Zürich: Diogenes Verlag, 1977.

. Sobre o fundamento da moral. Trad. Maria Lúcia Cacciola. São Paulo: Martins Fontes, 1995.

Recebido: $12 / 07 / 16$

Received: 07/12/16

Aprovado: $29 / 10 / 16$

Approved: 10/29/16

${ }^{29}$ Idem, p. 94.

Ser e sentido: o paradoxo do sofrimento 